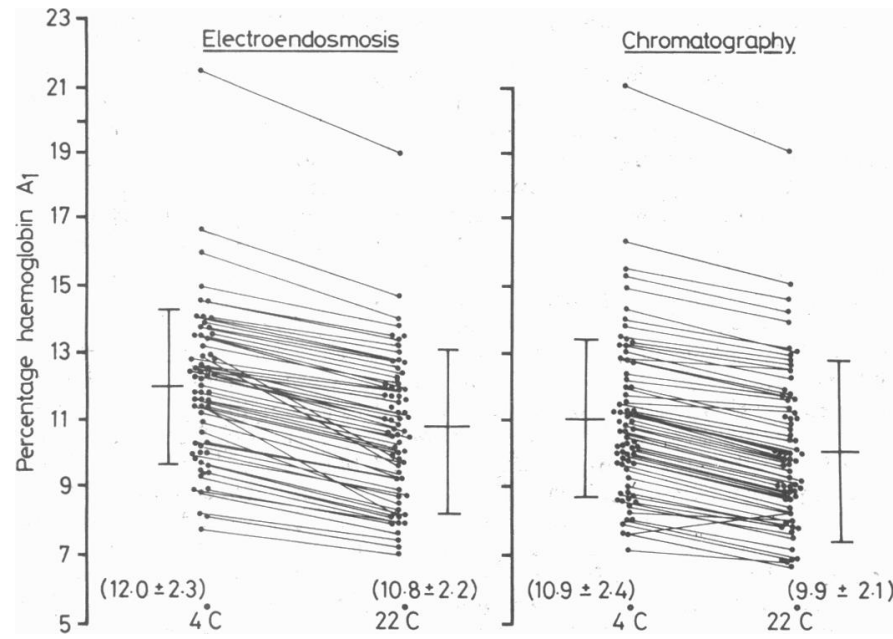

Changes in percentage of haemoglobin $A_{1}$ after incubation in $0.9 \%$ saline for 18 hours. Mean difference in percentage of haemoglobin $A_{1}$ was 1.2 SD 0.9 and $1.0 \pm 0.7(n=65)$ for electroendosmosis and chromatography respectively.

with reorganisation of the average diabetic clinic to permit at least one hour between blood sampling and consultation. This places further strain on both patients and clinic organisers but in our experience is worth while for both patient and physician. ${ }^{5}$

We thank the British Diabetic Association for financial support. CSC was the holder of a Medical Research Council training fellowship at the time that this work was done. We also thank Mrs Shirley Gunnell for her invaluable secretarial help.

${ }^{1}$ Svendsen PA, Christiansen IS, Welinch B, Nerup J. Fast glycosylation of haemoglobin. Lancet $1979 ; \mathrm{i}: 603$.

${ }^{2}$ Leslie R, Pyke DA, John PM, White JM. Fast glycosylation of haemoglobin. Lancet $1979 ; \mathrm{i}: 773-4$

${ }^{3}$ Widness JA, Roglet-Brown TL, Schwartz R. Rapid fluctuation in glycohaemoglobin $\left(\mathrm{HbA}_{1 \mathrm{c}}\right)$ related to acute changes in glucose. $\mathrm{F} \mathrm{Lab} \mathrm{Clin}$ Med $1980 ; 95: 386-94$.

- Baron MD, Sönksen PH, Shenouda FS. Microcolumn method for $\mathrm{HbA}_{1}$ determination. Lancet 1980;i:1114-6.

s Saunders J, Sönksen PH, Shenouda FS, Baron MD. Measuring glycosylated haemoglobin concentration in a diabetic clinic. $\mathrm{Br} \mathrm{Med} f$ $1980 ; 281$ : 1394 .

(Accepted 30 November 1981)

Department of Medicine, St Thomas's Hospital Medical School, London SE1 7EH

F S SHENOUDA, MB, MSC, research fellow

C S COCKRAM, BSC, MRCP, lecturer in medicine

$M$ D BARON, MA, research assistant

A TSATSOULIS, $M B$, visiting research fellow

LIN WEN HAN, MB, visiting research fellow

P H SÖNKSEN, MD, FRCP, professor of endocrinology

\section{Severe hyponatraemia and cardiac failure successfully treated with captopril}

Captopril, an orally active inhibitor of converting enzyme, has for some time been used to treat congestive cardiac failure and hypertension, particularly renovascular hypertension. ${ }^{1-3}$ We report on a patient with inoperable congenital heart disease and severe cardiac failure, resistant to conventional treatment, who developed profound hyponatraemia that responded to treatment with captopril.

\section{Case report}

A 29-year-old man with inoperable congenital cyanotic heart disease (transposition of the great vessels, high stenosis of the outflow of the right ventricle, and ventricular septal defect) was admitted on 18 April 1981 with severe ventricular failure and hyponatraemia (sodium concentration 125 $\mathrm{mmol}(\mathrm{mEq}) / 1$, potassium $4.6 \mathrm{mmol}(\mathrm{mEq}) / 1$, chloride $71 \mathrm{mmol}(\mathrm{mEq}) / 1$, urea $26.8 \mathrm{mmol} / 1(161 \mathrm{mg} / 100 \mathrm{ml})$, and creatinine $100 \mu \mathrm{mol} / 1(1.13 \mathrm{mg} / 100 \mathrm{ml}))$ A Pott's anastomosis had been carried out when he was 4 years old, and he had subsequently remained cyanosed with pulmonary hypertension and atrial fibrillation controlled by digoxin. In the nine years before admission his congestive cardiac failure had become increasingly difficult to control. Initially his progressive cardiac failure was treated with digoxin, high dose of diuretics (bumetanide $5 \mathrm{mg}$ twice daily, chlorthalidone $100 \mathrm{mg}$, and spironolactone $100 \mathrm{mg}$ daily) and vasodilator drugs (hydralazine $50 \mathrm{mg}$ twice daily, which he could not tolerate, and isosorbide dinitrate $20 \mathrm{mg}$ thrice daily, which was ineffective). His cardiac failure did not improve and by 1 June he was listless, drowsy, and confused. Serum electrolyte concentrations were: sodium $106 \mathrm{mmol} / 1$, potassium $3.9 \mathrm{mmol} / \mathrm{l}$, and chloride 59 $\mathrm{mmol} / \mathrm{l}$; urea concentration $30.8 \mathrm{mmol} / \mathrm{l}(185 \mathrm{mg} / 100 \mathrm{ml})$, creatinine 74 $\mu \mathrm{mol} / \mathrm{l}(837 \mu \mathrm{g} / 100 \mathrm{ml})$. Haemoglobin was $18 \cdot 3 \mathrm{~g} / \mathrm{dl}$, and packed cell volume $0.556(55.6 \%)$.

Because of the gross hyponatraemia and prerenal uraemia all drugs were stopped and captopril $25 \mathrm{mg}$ thrice daily was introduced. There was a rapid and large diuresis and a striking improvement in the clinical and biochemical state (figure). Nine days later diuretics were added in doses smaller than

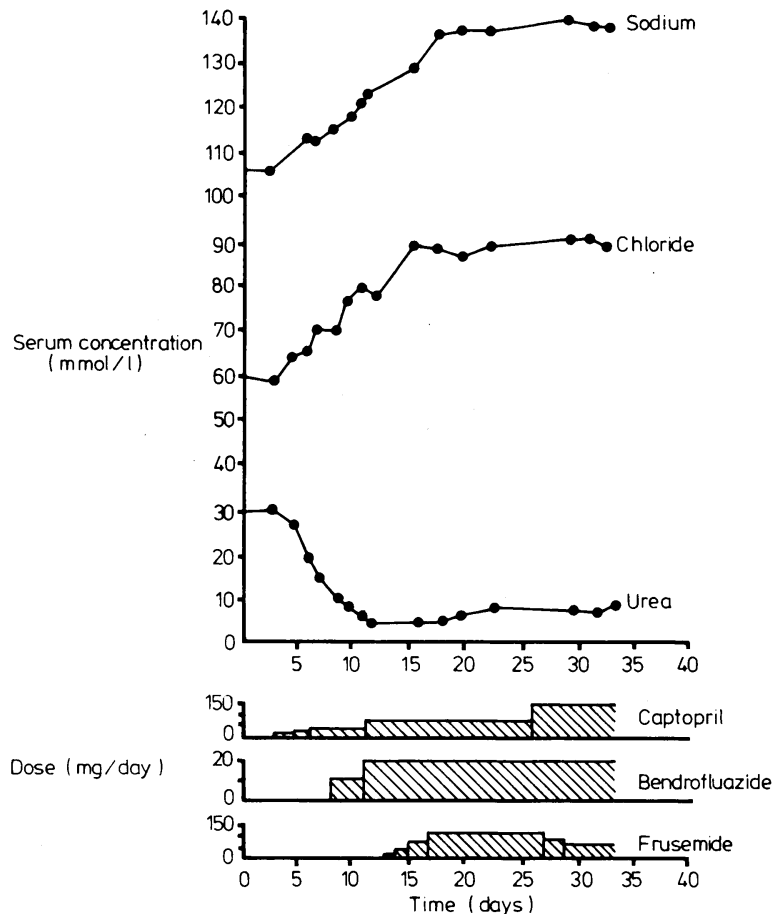

Electrolyte changes after introduction of captopril.

Conversion: SI to traditional units-Sodium: $1 \mathrm{mmol} / \mathrm{l}=1$ $\mathrm{mEq} / 1$. Chloride : $1 \mathrm{mmol} / \mathrm{l}=1 \mathrm{mEq} / 1$. Urea $: 1 \mathrm{mmol} / 1 \approx 6 \mathrm{mg} / 100$ $\mathrm{ml}$.

previously needed and captopril was increased to $50 \mathrm{mg}$ thrice daily. Serum biochemical concentrations returned to near normal (sodium $136 \mathrm{mmol} / \mathrm{l}$, potassium $4.2 \mathrm{mmol} / \mathrm{l}$, chloride $89 \mathrm{mmol} / \mathrm{l}$, urea $6.6 \mathrm{mmol} / 1(40 \mathrm{mg} / 100 \mathrm{ml})$, and creatinine $54 \mu \mathrm{mol} / \mathrm{l}(611 \mu \mathrm{g} / 100 \mathrm{ml}))$, and he was discharged home on 24 July taking captopril $50 \mathrm{mg}$ thrice daily, bendrofluazide $10 \mathrm{mg}$ twice daily, frusemide $80 \mathrm{mg}$ daily, digoxin $0.25 \mathrm{mg}$ daily, and warfarin. He remained well.

\section{Comment}

This patient with inoperable cyanotic congenital heart disease had not only congestive cardiac failure resistant to conventional treatment but also profound hyponatraemia. Previous work ${ }^{4}$ has shown that severe cardiac failure can cause constriction of the proximal glomerular capillaries, thus slowing the perfusion of the vasa recta loop with consequent retention of urea and hyponatraemia. Captopril could well correct these various postulated effects because in normal subjects and patients with essential hypertension it increases renal plasma flow and lowers renal vascular resistance, thus increasing glomerular filtration rate and creatinine clearance.

This effect, combined with captopril's other effects of improving cardiac output and decreasing systemic vascular resistance and ventricular filling pressure ${ }^{3}$ might explain our patient's rapid and 
dramatic response. We believe that this is the first report of successful treatment by captopril of a patient with intractable cardiac failure and profound hyponatraemia.

We thank Professor K G Lowe and Dr $\mathrm{H}$ Watson for permission to report this case, Dr D Maclean for advice on the use of captopril, and Miss A Scott for typing the manuscript.

Requests for reprints to Dr A N Shepherd, University Department of Medicine, Ninewells Hospital and Medical School, Dundee DD19SY.

1 Atkinson AB, Robertson JIS. Captopril in the treatment of clinical hypertension and cardiac failure. Lancet 1979 ;ii:836-9.

2 Turini GA, Brunner HR, Gribic M. Improvement of chronic congestive heart failure by oral captopril. Lancet 1979 ; :1213-5.

${ }^{3}$ Liebau G, Riegger AJG, Steilner H. Human dynamic effects of captopril in patients with congestive heart failure and hypertension. Amsterdam, Oxford, Princeton: Excerpta Medica, 1981:76-86.

4 Brown JJ, Davis DL, Johnstone VW, et al. Renin relationships in congestive cardiac failure, treated and untreated. Am Heart $\mathcal{F} 1970 ; 80$ : 329-42.

(Accepted 8 fanuary 1982)

University Department of Medicine, Ninewells Hospital and Medical School, Dundee DD1 9SY

A J MONTGOMERY, MB, CHB, medical registrar

A N SHEPHERD, BSC, MRCP, lecturer in medicine

D EMSLIE-SMITH, MD, FRCP, reader in medicine

\section{Smoking among patients with malignant hypertension}

Recent studies have shown that malignant hypertension is associated with excess smoking. ${ }^{1-3}$ In North Karelia, Finland, we have conducted a hypertension control programme since 1972 covering most hypertensive patients in the county, who have high cardiovascular morbidity and mortality. ${ }^{4}$ We report on the association between malignant hypertension and smoking in these Finnish patients, who are unselected and representative of the North Karelian population.

\section{Patients, methods, and results}

During 1972-7 there were 17014 registered hypertensive patients in North Karelia (9.6\% of the total population). A functional diagnosis was given to each person on admission to the register based on the WHO protocol for the co-operative study. The categories were (1) stage 1 disease (high blood pressure only); (2) stage 2 disease (high blood pressure with cardiovascular hypertrophy); (3) stage 3 disease (high blood pressure with evidence of organ damage attributable to the hypertension); (4) under observation waiting for more detailed examination because functional diagnoses have not been given; and (5) malignant hypertension. The criteria for the diagnosis of malignant hypertension were the appearance of bilateral exudates, retinal oedema, haemorrhages, and vascular thrombosis, usually with the additional finding of bilateral papilloedema. Because of the difficulty in distinguishing renal damage due to essential hypertension from primary renal diseases, patients with possible renal disease were included. In the malignant phase, however, renal disease progressed rapidly.

The evaluation of severe hypertension was usually carried out at the Central Hospital of North Karelia. Most of the patients with malignant hypertension were known to be hypertensive on admission to the register. Fifty-six patients (24 men, 32 women) were registered as having malignant hypertension. Eight patients were under 45 years and 12 over 65 . The ratio of men to women among patients with malignant hypertension was close to that among all patients on the register.

The registration of hypertensive patients was based on standardised record forms covering most relevant information. The forms were filled in by local doctors in health centres and hospitals according to detailed instructions. Standardisation and improvement of diagnostic and therapeutic procedures was one main task in this community-based programme to decrease blood pressure among the whole population mainly by treating as many hypertensive patients as possible in the population and by keeping the greatest possible number of patients under control. Current smoking was reported as the average number of cigarettes smoked daily.

In a representative population sample in 1977, 44 out of 913 men aged 30 to 44 and 43 out of 1034 men aged 45 to 64 were smokers; and 13 out of 879 women aged 30 to 44 and six out of 1222 women aged 45 to 64 were smokers. In this study 13 of the 24 men ( $54 \%$ ) and eight of the 32 women $(25 \%)$ were smokers (table). In comparison, the prevalence of smoking among men with other functional diagnoses varied between $33 \%$ and $37 \%$, and among women between $4 \%$ and $7 \%$. The difference between malignant and non-malignant groups was nearly significant $\left(x^{2}(1)=3 \cdot 7, p<0 \cdot 10\right)$ among men and significant $\left(x^{2}(1)=22.4, p<0.001\right)$ among women and among both sexes combined $\left(x^{2}(1)=17 \cdot 2, p<0 \cdot 001\right)$. In both sexes smoking among patients with malignant hypertension was more common in the youngest and oldest age groups than in the middle aged. Furthermore, among patients in the youngest age group (under 45 ) those with stage 3 hypertension tended to smoke significantly more $\left(x^{2}(1)=6 \cdot 0, p<0.05\right)$ than those with stage 1 or 2 disease, but not as much as those with malignant hypertension.

\section{Comment}

Our register of hypertension was based on the total population and, therefore, reflected the true position at the time the patients entered the register. No correlation was found between smoking and blood pressure. On the contrary, cigarette smoking among the patients, excluding those with malignant-phase hypertension, seemed to be lower than that among the general population, but differences were small. The prevalence of daily smoking among the general population aged 25 to 59 was $45 \%$ among men and $8 \%$ among women in 1972.4 Hypertensive patients on our register seem more likely to stop smoking than normotensive people. Stopping smoking should be encouraged early enough to prevent severe complications due to smoking, of which malignant hypertension is one: possible mechanisms have been discussed. ${ }^{12}$ There might also be another factor to which smokers are exposed-namely, cadmium-which causes tubular dysfunctions. 5 Our register may provide a basis for further prospective study of longterm effects of smoking in a hypertensive population.

1 Isles C, Brown JJ, Cumming AMM, et al. Excess smoking in malignantphase hypertension. Br Med 7 1979; i:579-81.

2 Bloxham CA, Beevers DG, Walker JM. Malignant hypertension and cigarette smoking. $\mathrm{Br}$ Med $\mathcal{F} 1979$;i :581-3.

${ }^{3}$ Elliot JM, Simpson FO. Cigarettes and accelerated hypertension. NZ Med $71980 ; 91: 447-9$.

4 Puska P, Tuomilehto J, Salonen J, et al. The North Karelia project: evaluation of a comprehensive community programme for control of cardiovascular diseases in 1972-1977 in North Karelia. WHO/EURO Monogr Ser (in press).

5 Tsuchiya K, King Sted S, Hamagami CM, eds. Cadmium studies in fapan. Amsterdam: Elsevier/North Holland and Biomedical Press, 1978.

(Accepted 2 October 1981)

North Karelia Project, University of Kuopio, PO Box 40, 70101 Kuopio 10, Finland

JAAKKO TUOMILEHTO, MD, MA, assistant professor, regional adviser on cardiovascular and metabolic diseases (present address: WHO Regional Office for the Western Pacific, PO Box 2932, Manila, Philippines)

JYRKI ELO, MD, research investigator

AULIKKI NISSINEN, MD, senior research investigator (present address National Public Health Laboratory of Finland, Epidemiological Research Unit, Helsinki, Finland)

Prevalence of smoking among hypertensive patients on admission to register by age, sex, and functional diagnosis. Figures are proportions of patients smoking (and percentages) in each group

\begin{tabular}{|c|c|c|c|c|c|c|c|c|}
\hline & \multicolumn{4}{|c|}{ Men } & \multicolumn{4}{|c|}{ Women } \\
\hline & $15-44$ & $45-64$ & Over 65 & Total & $15-44$ & $45-64$ & Over 65 & Total \\
\hline $\begin{array}{l}\text { Under observation } \\
\text { (stage IV) } \\
\text { Stage I } \\
\text { Stage II } \\
\text { Stage III } \\
\text { Malignant hypertension }\end{array}$ & $\begin{array}{c}20 / 61(33) \\
642 / 1562(41) \\
80 / 194(41) \\
45 / 76(59) \\
3 / 4(75)\end{array}$ & $\begin{array}{c}23 / 61(38) \\
679 / 1884(36) \\
241 / 645(37) \\
244 / 692(35) \\
8 / 17(47)\end{array}$ & $\begin{array}{c}5 / 21(24) \\
90 / 400(23) \\
53 / 288(18) \\
70 / 334(21) \\
2 / 3(67)\end{array}$ & $\begin{array}{c}48 / 143(34) \\
1141 / 3846(37) \\
374 / 1127(33) \\
359 / 1102(33) \\
13 / 24(54)\end{array}$ & $\begin{array}{c}1 / 25(4) \\
151 / 1083(14) \\
7 / 100(7) \\
10 / 62(16) \\
1 / 4(25)\end{array}$ & $\begin{array}{c}5 / 62(8) \\
230 / 3585(6) \\
70 / 1348(5) \\
38 / 925(4) \\
3 / 19(16)\end{array}$ & $\begin{array}{c}0 / 24(0) \\
23 / 1189(2) \\
19 / 997(2) \\
26 / 938(3) \\
4 / 9(44)\end{array}$ & $\begin{array}{c}6 / 111(5) \\
404 / 5857(7) \\
96 / 2445(4) \\
74 / 1925(4) \\
8 / 32(25)\end{array}$ \\
\hline
\end{tabular}

